\title{
Laceyella sediminis sp. nov., a thermophilic bacterium isolated from a hot spring
}

\author{
Correspondence \\ Wen-Jun Li \\ wjli@ynu.edu.cn \\ Lian-Bing Lin \\ linlb@sohu.com
}

\author{
Jiu-Jiu Chen, ${ }^{1,2}$ Lian-Bing Lin, ${ }^{1}$ Lan-Lan Zhang, ${ }^{1}$ Jin Zhang, ${ }^{2}$ \\ Shu-Kun Tang, ${ }^{1}$ Yun-Lin Wei ${ }^{1}$ and Wen-Jun $\mathrm{Li}^{2}$ \\ ${ }^{1}$ Biotechnology Research Center, Faculty of Life Science and Technology, \\ Kunming University of Science and Technology (KUST), Kunming 650093, PR China \\ ${ }^{2}$ Key Laboratory of Microbial Diversity in Southwest China, Ministry of Education, PR China, and \\ Laboratory for Conservation and Utilization of Bio-Resources, Yunnan Institute of Microbiology, \\ Yunnan University, Kunming 650091, PR China
}

\begin{abstract}
A thermophilic bacterium, designated strain $\mathrm{RHA}^{\top}$, was isolated from a sediment sample collected from a hot spring in Tengchong county, Yunnan province, south-west China, and was characterized by using a polyphasic approach. Based on its phenotypic and phylogenetic characteristics, strain $\mathrm{RHA}^{\top}{ }^{\top}$ was affiliated to the genus Laceyella. The strain formed white aerial and yellow-white substrate mycelia, bearing single endospores on short sporophores. The cell-wall peptidoglycan contained meso-diaminopimelic acid. Whole-cell hydrolysates contained ribose and glucose. The major fatty acids were iso- $\mathrm{C}_{15: 0}(62.39 \%)$ and anteiso- $\mathrm{C}_{15: 0}(17.55 \%)$ The predominant menaquinone was MK-9. The $\mathrm{G}+\mathrm{C}$ content of the genomic DNA of strain $\mathrm{RHA}^{\top}{ }^{\top}$ was 47.9 mol\%. Based on DNA-DNA hybridization data, chemotaxonomic characteristics and differential physiological properties, strain $\mathrm{RHA}^{\top}{ }^{\top}$ is considered to represent a novel species of the genus Laceyella, for which the name Laceyella sediminis sp. nov. is proposed; the type strain is RHA1 ${ }^{\top}\left(=\mathrm{DSM} 45263^{\top}=\right.$ CCTCC AA $\left.208058^{\top}\right)$.
\end{abstract}

The genus Laceyella within the family Bacillaceae was proposed by Yoon et al. (2005), but was subsequently placed in the family Thermoactinomycetaceae by Matsuo et al. (2006) based on data from a polyphasic taxonomic study. Members of the genus Laceyella are aerobic, chemoorganotrophic, Gram-positive and thermophilic filamentous bacteria. Substrate and aerial mycelia are formed, and the aerial mycelium is white. Sessile endospores may be produced on sporophores. Greyish-yellow or yellowbrown diffusible pigment may be produced. The predominant menaquinone is MK-9. The cell-wall peptidoglycan contains meso-diaminopimelic acid, but no characteristic sugars. The major fatty acids are iso- $\mathrm{C}_{15: 0}$ and anteiso$\mathrm{C}_{15: 0}$, and the DNA $\mathrm{G}+\mathrm{C}$ content of the type strains of recognized Laceyella species is in the range 48-49 mol\% (Yoon et al., 2005). At the time of writing, the genus comprised three recognized species: Laceyella sacchari (basonym Thermoactinomyces sacchari; Lacey \& Vince, 1971; Yoon et al., 2000, 2005), Laceyella putida (basonym Thermoactinomyces putidus; Lacey \& Cross, 1989; Yoon et al., 2005) and Laceyella tengchongensis (Zhang et al., 2010).

The GenBank/EMBL/DDBJ accession number for the 16S rRNA gene sequence of strain RHA1 ${ }^{\top}$ is FJ422144.

Two supplementary figures are available with the online version of this paper.
During long-term investigations on the diversity of microorganisms from particular habitats, a thermophilic strain, designated $R H A 1^{\mathrm{T}}$, was isolated from a sediment sample of a hot spring $\left(55^{\circ} \mathrm{C}, \mathrm{pH}\right.$ 6.5). In this study, $1 \mathrm{~g}$ sediment was suspended in $50 \mathrm{ml}$ liquid DSM 88 medium and incubated at $55{ }^{\circ} \mathrm{C}$ with shaking (140 r.p.m.) for $24 \mathrm{~h}$. Samples of $100 \mu \mathrm{l}$ were then spread onto the surface of isolation plates containing soluble starch $(1.0 \%, \mathrm{w} / \mathrm{v})$ and incubated at $55{ }^{\circ} \mathrm{C}$ for $24 \mathrm{~h}$. After three purification steps, one strain, designated $\mathrm{RHAl}^{\mathrm{T}}$, was picked from the isolation plate and maintained on DSM 88 medium agar slants at $4{ }^{\circ} \mathrm{C}$ and as glycerol suspensions $(20 \%$, v/v) at $-80{ }^{\circ} \mathrm{C}$.

Cultures grown on International Streptomyces Project (ISP) 3 agar medium (Shirling \& Gottlieb, 1966) for 1-7 days at $55{ }^{\circ} \mathrm{C}$ were observed by light microscopy (Olympus BH-2). The colours of substrate and aerial mycelia and any soluble pigments produced were determined with reference to Kelly (1964). Aerial and substrate mycelia were abundant, well developed, non-fragmented and white; endospores were formed (Fig. 1). Scanning electron micrographs (Philip XL30 ESEM-TMP) were taken of mature spores in aerial mycelia of strain $\mathrm{RHAl}^{\mathrm{T}}$ grown on ISP 3 agar medium for 5 days at $55{ }^{\circ} \mathrm{C}$.

The physiological features and biochemical characteristics of strain $\mathrm{RHAl}^{\mathrm{T}}$ were examined as described by 

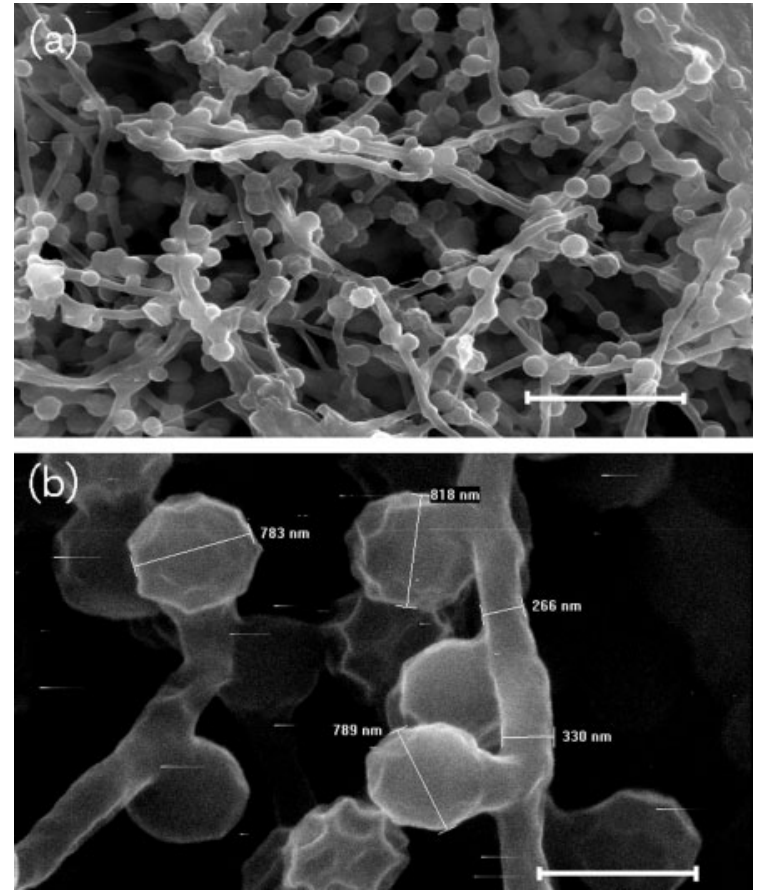

Fig. 1. Scanning electron micrographs of mature spores in aerial mycelia of strain $\mathrm{RHA}^{\top}{ }^{\top}$ grown on ISP 3 agar medium for 5 days at $55{ }^{\circ} \mathrm{C}$. Representative measurements are given in (b). Bars: (a) $5 \mu \mathrm{m}$; (b) $1 \mu \mathrm{m}$.

Goodfellow (1971) and Williams et al. (1983) and are detailed in Table 1 and in the species description. Growth of strain RHA $1^{\mathrm{T}}$ occurred at $28-65{ }^{\circ} \mathrm{C}$ (optimum $55^{\circ} \mathrm{C}$ ), at $\mathrm{pH}$ 5.0-9.0 (optimum pH 7.0) and in the presence of 0 $1 \%(\mathrm{w} / \mathrm{v}) \mathrm{NaCl}$ (optimum $0 \%)$. The phenotypic properties of strain $\mathrm{RHAl}^{\mathrm{T}}$ clearly distinguished it from recognized Laceyella species (Tables 1 and 2).

For chemical and molecular systematic studies, biomass of strain $\mathrm{RHAl}^{\mathrm{T}}$ and the type strains of $L$. sacchari, L. putida and $L$. tengchongensis was obtained after incubation in DSM 88 broth at $55{ }^{\circ} \mathrm{C}$ for 3 days in shaken flasks (about 150 r.p.m.). Amino acids and sugars of whole-cell hydrolysates were analysed according to the procedures described by Hasegawa et al. (1983). Polar lipids were extracted and examined by two-dimensional TLC and were identified by using the procedures described by Minnikin et al. (1984) (see Supplementary Fig. S1 in IJSEM Online). Menaquinones were extracted according to Minnikin et al. (1984) and were analysed by HPLC (Kroppenstedt, 1982). Cellular fatty acid assays were performed according to the standard protocol of the Microbial Identification System (MIDI) (Sasser, 1990) (Sherlock version 6.1; MIDI database TSBA6), according to the manufacturer's instructions. Whole-cell hydrolysates of strain $\mathrm{RHAl}^{\mathrm{T}}$ contained mesodiaminopimelic acid, ribose and glucose. The phospholipids comprised disphosphatidylglycerol, phosphatidylethanolamine, phosphatidylglycerol, phosphatidylinositol, phosphatidylinositolmannosides and one unknown phospholipid.
The predominant menaquinone was MK-9; MK-8 was detected as a minor component. The cellular fatty acids included branched, straight-chain and unsaturated components (Kroppenstedt, 1985). The major fatty acids were iso$\mathrm{C}_{15: 0}(62.39 \%)$ and anteiso- $\mathrm{C}_{15: 0}(17.55 \%)$. A detailed fatty acid profile of strain $\mathrm{RHAl}^{\mathrm{T}}$ is given in Table 2; it was similar to those of L. sacchari DSM $43356^{\mathrm{T}}$, L. putida DSM $44608^{\mathrm{T}}$ and L. tengchongensis $\mathrm{YIM} 10002^{\mathrm{T}}$.

Extraction of genomic DNA, and PCR amplification and sequencing of the $16 \mathrm{~S}$ rRNA gene of strain $\mathrm{RHAl}^{\mathrm{T}}$ were carried out according to Li et al. (2007). The almostcomplete 16S rRNA gene sequence (1467 bp) of strain $\mathrm{RHAl}^{\mathrm{T}}$ was determined. The $16 \mathrm{~S}$ rRNA gene sequence of strain $\mathrm{RHAl}^{\mathrm{T}}$ was compared with available sequences from GenBank by using the program BLAST (http://blast.ncbi.nlm. nih.gov/Blast.cgi) to determine an approximate phylogenetic affiliation. The program CLUSTAL $\mathrm{x}$ (Thompson et al., 1997) was used for multiple alignment and three algorithms, neighbour-joining (Saitou \& Nei, 1987), maximumparsimony (Fitch, 1971) and maximum-likelihood (Guindon \& Gascuel, 2003), were used to construct phylogenetic trees; Bacillus subtilis NCDO $1769^{\mathrm{T}}$ was used as an outgroup. The topology of the trees generated with these methods was evaluated by the bootstrap resampling method of Felsenstein (1985) based on 1000 resamplings.

A BLAST analysis of the 16S rRNA gene sequence of strain $\mathrm{RHAl}^{\mathrm{T}}$ showed that it was affiliated to the family Thermoactinomycetaceae. Fig. 2 shows the phylogenetic position of strain $\mathrm{RHAl}^{\mathrm{T}}$ within the radiation of species of the genus Laceyella. Strain $\mathrm{RHAl}^{\mathrm{T}}$ occupied a distinct branch with $L$. sacchari DSM $43356^{\mathrm{T}}$, L. tengchongensis YIM $10002^{\mathrm{T}}$ and L. putida DSM $44608^{\mathrm{T}}$, with which it shared 99.8, 99.6 and $97.8 \% 16 \mathrm{~S}$ rRNA gene sequence similarity, respectively. This position was also supported in the tree generated with the maximum-likelihood algorithm with a bootstrap value of $100 \%$ (Supplementary Fig. S2, available in IJSEM Online).

For determination of the $\mathrm{G}+\mathrm{C}$ content of strain $\mathrm{RHAl}^{\mathrm{T}}$, DNA was obtained according to the method described by Marmur (1961) and the value was determined by the HPLC method (Mesbah et al., 1989). The DNA G+C content of strain $\mathrm{RHAl}^{\mathrm{T}}$ was $47.9 \mathrm{~mol} \%$. DNA-DNA hybridization was carried out by the optical renaturation method (De Ley et al., 1970; Huß et al., 1983; Jahnke, 1992). Levels of DNA-DNA relatedness between strain RHA1 $^{\mathrm{T}}$ and its closest phylogenetic neighbours, L. sacchari DSM $43356^{\mathrm{T}}$, L. tengchongensis YIM $10002^{\mathrm{T}}$ and L. putida DSM $44608^{\mathrm{T}}$, were 60,47 and $44 \%$, respectively, values below the $70 \%$ threshold for the delineation of genomic species (Stackebrandt \& Goebel, 1994).

Based on the combination of morphological, physiological, chemotaxonomic and phylogenetic data discussed here, it is evident that strain RHAl $^{\mathrm{T}}$ should be affiliated to the genus Laceyella. Differences in several phenotypic characteristics can be used to distinguish the isolate from recognized Laceyella species. For example, strain $\mathrm{RHAl}^{\mathrm{T}}$ 
Table 1. Differential characteristics between strain $\mathrm{RHA} 1^{\top}$ and the type strains of recognized species of the genus $L a c e y e l l a$ Strains: 1 , RHA1 ${ }^{\mathrm{T}} ; 2$, L. sacchari DSM $43356^{\mathrm{T}}$; 3, L. tengchongensis YIM $10002^{\mathrm{T}} ; 4$, L. putida DSM $44608^{\mathrm{T}}$. All data are from this study. $\mathrm{V}$, Variable.

\begin{tabular}{|c|c|c|c|c|}
\hline Characteristic & 1 & 2 & 3 & 4 \\
\hline Soluble pigment & - & Yellow-brown & - & Greyish-yellow \\
\hline Melanin & - & V & - & + \\
\hline \multicolumn{5}{|l|}{ Degradation of: } \\
\hline Hypoxanthine & + & - & + & - \\
\hline Starch & + & + & - & + \\
\hline Gelatin liquefaction & + & - & + & + \\
\hline Temperature range $\left({ }^{\circ} \mathrm{C}\right)$ & $28-65$ & $35-65$ & $28-70$ & $30-65$ \\
\hline \multicolumn{5}{|l|}{ Utilization of: } \\
\hline D-Mannitol & - & + & + & - \\
\hline L-Rhamnose & - & - & + & - \\
\hline Raffinose & - & + & - & - \\
\hline Maltose & + & + & - & + \\
\hline L-Lysine & - & - & + & - \\
\hline L-Cysteine & - & + & + & - \\
\hline L-Threonine & - & - & + & + \\
\hline Glycine & + & + & - & + \\
\hline L-Serine & - & + & - & + \\
\hline Adenine & + & - & - & - \\
\hline L-Valine & + & - & - & + \\
\hline Xanthine & + & - & - & + \\
\hline L-Proline & + & - & - & + \\
\hline \multicolumn{5}{|l|}{ Chemotaxonomic data: } \\
\hline Whole-cell sugars ${ }^{\star}$ & Rib, Glu & Xyl, Ara, Glu & Rib, Xyl, Glu & Xyl, Ara, Glu \\
\hline Phospholipid components $\dagger$ & $\begin{array}{c}\text { DPG, PE, PG, } \\
\text { PI, PIM, PL }\end{array}$ & $\begin{array}{c}\text { DPG, PE, PME, } \\
\text { PI, PIM, PL }\end{array}$ & $\begin{array}{c}\text { DPG, PE, PG, } \\
\text { PI, PIM, PL }\end{array}$ & $\begin{array}{c}\text { DPG, PE, PG, } \\
\text { PI, PIM, PL }\end{array}$ \\
\hline Menaquinones & MK-9, MK-8 & MK-9, MK-8, MK-10 & MK-9, MK-8 & MK-9, MK-8 \\
\hline DNA G $+\mathrm{C}$ content $(\mathrm{mol} \%)$ & 47.9 & 48.0 & 48.6 & 49.0 \\
\hline
\end{tabular}

${ }^{*}$ Ara, Arabinose; Glu, glucose; Rib, ribose; Xyl, xylose.

$\nmid$ DPG, Disphosphatidylglycerol; PE, phosphatidylethanolamine; PG, phosphatidylglycerol; PI, phosphatidylinositol; PIM, phosphatidylinositolmannosides; PME, phosphatidylmonomethylethanolamine; PL, unknown phospholipid.

Table 2. Cellular fatty acid profiles of strain $\mathrm{RHA}^{\top}$ and type strains of recognized species of the genus Laceyella

Strains: $1, \mathrm{RHAl}^{\mathrm{T}}$; 2, L. sacchari DSM $43356^{\mathrm{T}} ; 3$, L. tengchongensis DSM $45262^{\mathrm{T}} ; 4$, L. putida DSM $44608^{\mathrm{T}}$. All data are from this study; cultures were grown under identical conditions. Values are percentages of the total fatty acids.

\begin{tabular}{|c|c|c|c|c|}
\hline Fatty acid & 1 & 2 & 3 & 4 \\
\hline \multicolumn{5}{|l|}{ Straight-chain } \\
\hline $\mathrm{C}_{14: 0}$ & 2.24 & 1.27 & 1.16 & 1.12 \\
\hline $\mathrm{C}_{16: 0}$ & 2.62 & 1.47 & 1.61 & 1.05 \\
\hline $\mathrm{C}_{17: 0}$ & 0.53 & 0.91 & 0.85 & 1.06 \\
\hline \multicolumn{5}{|c|}{ Branched-chain } \\
\hline iso- $\mathrm{C}_{13: 0}$ & 0.83 & 1.30 & 1.32 & 1.90 \\
\hline iso- $\mathrm{C}_{14: 0}$ & 2.38 & 3.28 & 7.11 & 9.89 \\
\hline iso- $\mathrm{C}_{15: 0}$ & 62.39 & 66.61 & 57.63 & 50.66 \\
\hline anteiso- $\mathrm{C}_{15: 0}$ & 17.55 & 12.02 & 13.79 & 18.34 \\
\hline iso- $\mathrm{C}_{16: 0}$ & 4.18 & 4.36 & 8.88 & 9.68 \\
\hline iso- $\mathrm{C}_{17: 0}$ & 4.43 & 4.15 & 3.62 & 3.53 \\
\hline anteiso- $\mathrm{C}_{17: 0}$ & 1.82 & 0.89 & 1.18 & 1.77 \\
\hline
\end{tabular}

and the type strains of $L$. sacchari, L. tengchongensis and $L$. putida showed different results for gelatin liquefaction, starch hydrolysis, nitrate reduction and melanin production. They could also be distinguished based on cell-wall sugars and DNA G $+\mathrm{C}$ content. The above data, together with low levels of DNA-DNA relatedness $(<70 \%)$ between strain $\mathrm{RHAl}^{\mathrm{T}}$ and its closest phylogenetic neighbours, demonstrate that strain $\mathrm{RHAl}^{\mathrm{T}}$ represents a novel species of the genus Laceyella, for which the name Laceyella sediminis sp. nov. is proposed.

\section{Description of Laceyella sediminis sp. nov.}

Laceyella sediminis (se.di'mi.nis. L. gen. n. sediminis of sediment).

Cells are Gram-positive, aerobic, thermophilic and filamentous. White aerial and yellow-white substrate mycelia are produced, bearing single endospores on short sporophores. No soluble pigments are produced on any of the media tested. Growth occurs at $28-65{ }^{\circ} \mathrm{C}$ (optimum $55{ }^{\circ} \mathrm{C}$ ), at $\mathrm{pH}$ 5.0-9.0 (optimum $\mathrm{pH} 7.0$ ) and in the 


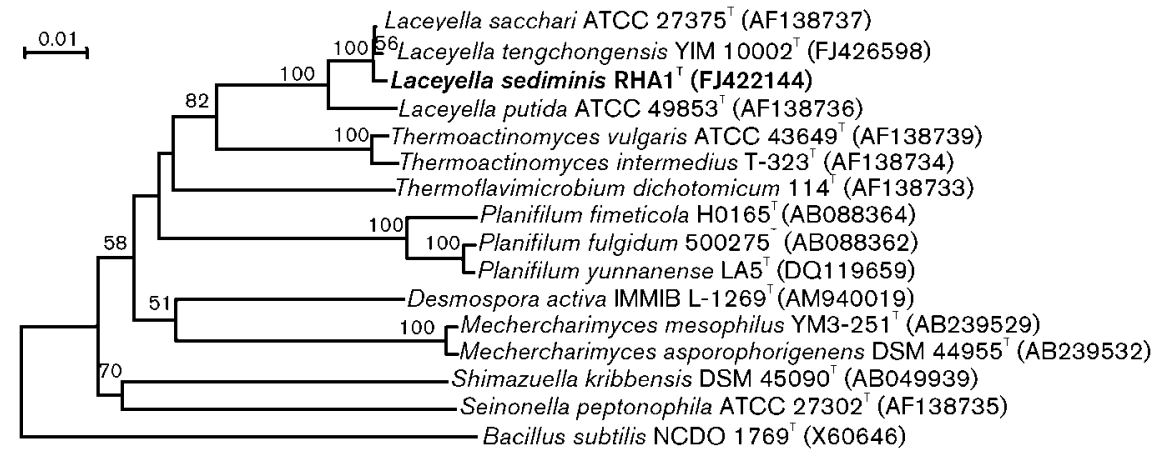

Fig. 2. Neighbour-joining phylogenetic dendrogram based on nearly complete $16 \mathrm{~S}$ rRNA gene sequences showing the position of strain $\mathrm{RHA}^{\top}{ }^{\top}$ among its closest neighbours. Numbers at nodes are bootstrap values (percentages of 1000 replications); only values $>50 \%$ are shown. The sequence of Bacillus subtilis NCDO $1769^{\top}$ was used as an outgroup. Bar, 0.01 inferred substitutions per site.

presence of $0-1 \%(\mathrm{w} / \mathrm{v}) \mathrm{NaCl}$ (optimum $0 \%$ ). Positive for gelatin liquefaction, degradation of starch, and milk peptonization and coagulation, but negative for nitrate reduction, and $\mathrm{H}_{2} \mathrm{~S}$ and melanin production. Utilizes lactose, trehalose, maltose and gelatin as carbon sources, but not D-mannitol, L-rhamnose, raffinose, D-mannose, D-xylose or D-ribose. Degrades L-proline, xanthine, L-valine, adenine, glycine, L-asparagine and L-arginine, but not L-lysine, L-cysteine, L-threonine, L-serine or Lhydroxyproline. The diagnostic amino acid in the peptidoglycan is meso-diaminopimelic acid. Hydrolysates of the cell-wall contain ribose and glucose. The predominant menaquinone is MK-9. The major cellular fatty acids are iso- $\mathrm{C}_{15: 0}$ and anteiso- $\mathrm{C}_{15: 0}$.

The type strain is $\mathrm{RHAl}^{\mathrm{T}}\left(=\mathrm{DSM} 45263^{\mathrm{T}}=\mathrm{CCTCC}\right.$ AA $208058^{\mathrm{T}}$ ), isolated from a sediment sample of a hot spring collected from Tengchong county, Yunnan province, south-west China. The DNA G $+\mathrm{C}$ content of the type strain is $47.9 \mathrm{~mol} \%$.

\section{Acknowledgements}

We are grateful to Professor Hans-Peter Klenk for the reference type strains. This research was supported by the National Basic Research Program of China (no. 2010CB833801) and National Natural Science Foundation of China (nos 31070007 and 30960022).

\section{References}

De Ley, J., Cattoir, H. \& Reynaerts, A. (1970). The quantitative measurement of DNA hybridization from renaturation rates. Eur $J$ Biochem 12, 133-142.

Felsenstein, J. (1985). Conference limits on phylogenies: an approach using the bootstrap. Evolution 39, 783-791.

Fitch, W. M. (1971). Toward defining the course of evolution: minimum change for a specific tree topology. Syst Zool 20, 406-416.

Goodfellow, M. (1971). Numerical taxonomy of some nocardioform bacteria. J Gen Microbiol 69, 33-80.
Guindon, S. \& Gascuel, O. (2003). A simple, fast, and accurate algorithm to estimate large phylogenies by maximum likelihood. Syst Biol 52, 696-704.

Hasegawa, T., Takizawa, M. \& Tanida, S. (1983). A rapid analysis for chemical grouping of aerobic actinomycetes. J Gen Appl Microbiol 29, 319-322.

Huß, V. A. R., Festl, H. \& Schleifer, K. H. (1983). Studies on the spectrophotometric determination of DNA hybridization from renaturation rates. Syst Appl Microbiol 4, 184-192.

Jahnke, K. D. (1992). Basic computer program for evaluation of spectroscopic DNA renaturation data from GILFORD system 2600 spectrophotometer on a PC/XT/AT type personal computer. J Microbiol Methods 15, 61-73.

Kelly, K. L. (1964). Inter-Society Color Council - National Bureau of Standards Color Name Charts Illustrated with Centroid Colors. Washington, DC: US Government Printing Office.

Kroppenstedt, R. M. (1982). Separation of bacterial menaquinones by HPLC using reverse phase (RP 18) and a silver loaded ion exchanger as stationary phases. J Liq Chromatogr 5, 2359-2367.

Kroppenstedt, R. M. (1985). Fatty acid and menaquinone analysis of actinomycetes and related organisms. In Chemical Methods in Bacterial Systematics, pp. 173-199. Edited by M. Goodfellow \& D. E. Minnikin. London: Academic Press.

Lacey, J. \& Cross, T. (1989). Genus Thermoactinomyces Tsiklinsky $1899,501^{\mathrm{AL}}$. In Bergey's Manual of Systematic Bacteriology, vol. 4, pp. 2574-2585. Edited by S. T. Williams, M. E. Sharpe \& J. G. Holt. Baltimore: Williams \& Wilkins.

Lacey, J. \& Vince, D. A. (1971). Endospore formation and germination in a new Thermoactinomyces species. In Spore Research, pp. 181-187. Edited by A. N. Barker, G. W. Gould \& J. A. Wolf. London: Academic Press.

Li, W. J., Xu, P., Schumann, P., Zhang, Y. Q., Pukall, R., Xu, L. H., Stackebrandt, E. \& Jiang, C. L. (2007). Georgenia ruanii sp. nov., a novel actinobacterium isolated from forest soil in Yunnan (China), and emended description of the genus Georgenia. Int J Syst Evol Microbiol 57, 1424-1428.

Marmur, J. (1961). A procedure for the isolation of deoxyribonucleic acid from microorganisms. J Mol Biol 3, 208-218.

Matsuo, Y., Katsuta, A., Matsuda, S., Shizuri, Y., Yokota, A. \& Kasai, H. (2006). Mechercharimyces mesophilus gen. nov., sp. nov. and Mechercharimyces asporophorigenens sp. nov., antitumour substance-producing 
marine bacteria, and description of Thermoactinomycetaceae fam. nov. Int J Syst Evol Microbiol 56, 2837-2842.

Mesbah, M., Premachandran, U. \& Whitman, W. B. (1989). Precise measurement of the $\mathrm{G}+\mathrm{C}$ content of deoxyribonucleic acid by high-performance liquid chromatography. Int J Syst Bacteriol 39, 159-167.

Minnikin, D. E., O'Donnell, A. G., Goodfellow, M., Alderson, G., Athalye, M., Schaal, A. \& Parlett, J. H. (1984). An integrated procedure for the extraction of bacterial isoprenoid quinones and polar lipids. J Microbiol Methods 2, 233-241.

Saitou, N. \& Nei, M. (1987). The neighbor-joining method: a new method for reconstructing phylogenetic trees. Mol Biol Evol 4, 406425.

Sasser, M. (1990). Identification of bacteria by gas chromatography of cellular fatty acids. USFCC Newsl 20, 16.

Shirling, E. B. \& Gottlieb, D. (1966). Methods for characterization of Streptomyces species. Int J Syst Bacteriol 16, 313-340.

Stackebrandt, E. \& Goebel, B. M. (1994). Taxonomic note: a place for DNA-DNA reassociation and $16 \mathrm{~S}$ rRNA sequence analysis in the present species definition in bacteriology. Int J Syst Bacteriol 44, 846-849.
Thompson, J. D., Gibson, T. J., Plewniak, F., Jeanmougin, F. \& Higgins, D. G. (1997). The CLUSTAL_X windows interface: flexible strategies for multiple sequence alignment aided by quality analysis tools. Nucleic Acids Res 25, 4876-4882.

Williams, S. T., Goodfellow, M., Alderson, G., Wellington, E. M. H., Sneath, P. H. A. \& Sackin, M. J. (1983). Numerical classification of Streptomyces and related genera. J Gen Microbiol 129, 1743-1813.

Yoon, J.-H., Shin, Y. K. \& Park, Y.-H. (2000). DNA-DNA relatedness among Thermoactinomyces species: Thermoactinomyces candidus as a synonym of Thermoactinomyces vulgaris and Thermoactinomyces thalpophilus as a synonym of Thermoactinomyces sacchari. Int J Syst Evol Microbiol 50, 1905-1908.

Yoon, J.-H., Kim, I.-G., Shin, Y.-K. \& Park, Y.-H. (2005). Proposal of the genus Thermoactinomyces sensu stricto and three new genera, Laceyella, Thermoflavimicrobium and Seinonella, on the basis of phenotypic, phylogenetic and chemotaxonomic analyses. Int J Syst Evol Microbiol 55, 395-400.

Zhang, J., Tang, S.-K., Zhang, Y.-Q., Yu, L.-Y., Klenk, H.-P. \& Li, W. J. (2010). Laceyella tengchongensis sp. nov., a thermophilic strain isolated from soil of a volcano. Int J Syst Evol Microbiol 60, 22262230 . 